\title{
Cerebral Hemisphere Lipoma
}

National Cancer Institute

\section{Source}

National Cancer Institute. Cerebral Hemisphere Lipoma. NCI Thesaurus. Code C6220.

A rare benign adipose tissue neoplasm within the cerebral hemisphere often associated with partial or complete agenesis of the corpus callosum. 